Ritrýnd grein birt 31. desember 2018

\title{
Kennsluhættir speglaðir í ljósi sjálfræðis: Virðing, ábyrgð og traust
}

\author{
Hafdís Ingvarsdóttir
}

\begin{abstract}
Um höfundinn $>$ About the author Heimildir
Alla síðustu öld og fram á pennan dag hafa fræðimenn bent á mikilvægi pess að skólastarf byggist á lýðræði og félagslegu réttlæti. Margar leiðir hafa verið nefndar að slíkum markmiðum en petta hefur reynst hægara sagt en gert. Hugmyndin um sjálfræði kennara og nemenda er eitt af pví sem talið hefur verið að gegni mikilvægu hlutverki við að efla félagslegt réttlæti. Hér verða kennsluhættir skoðaðir í ljósi kenninga um sjálfrææð í starfsháttum í námi og kennslu. Markmiðið var að kanna með vettvangsathugunum hvort og pá hvernig kennarar stuðluðu að sjálfræði með starfsháttum sínum. Sjálfræði kennara og nemenda og undirliggjandi gildi pess, virðing, ábyrgð og traust, eru skilgreind sem ein forsenda félagslegt réttlætis í námi og kennslu. Gögnin sem lögð eru til grundvallar eru vettvangsathuganir úr 130 kennslustundum í framhaldsskólum. Notuð var aðleiðsla við greiningu gagnanna og komu pá fram fimm flokkar: Miðstýrð kennsla, prófastýring, viðleitni og virkni, í átt til sjálfræðis og loks nemendasjálfræði í verki. Sýnd eru dæmi úr hverjum flokki, pau skýrð og rædd. Niðurstaðan gefur ákveðna vísbendingu um að prátt fyrir frjálslynda námskrá og mikið formlegt frelsi sem skólarnir hafa til að móta starfshætti hafi kennsluhættir í anda sjálfræðis almennt ekki nád að festa rætur.
\end{abstract}

Efnisord: Aðalnámskrá, kennsluhættir, nemendasjálfræði, kennarasjálfræði

\section{Inngangur}

Fjöldi fræðimanna hefur fjallað ítarlega um mikilvægi lýðræðis í skólastarfi. Rekja má pá umræðu allt aftur til Dewey (1916/2007) og af nýlegri dæmum má nefna Sigrúnu Aðalbjarnardóttur (2007, 2015), Biesta (2007) og Oser, Dick og Patry (1992). Á undanförnum árum hafa komið fram raddir sem benda á að til að próa betra samfélag purfi að efla lýðræðisvitund ungs fólks, ekki síst innan skólanna. Sigrún Aðalbjarnardóttir (2015) leggur áherslu á að ekki gangi að taka lýðræðinu sem gefnu heldur purfi að hlúa markvisst að pví. Einn páttur lýðræðisvitundar er vitundin um félagslegt réttlæti, vitund um og skilningur á að allir skuli hafa jafnan rétt í pjóðfélaginu án tillits til kynferðis, kynhneigðar, trúarbragða, litarháttar og uppruna og fullt jafnrétti til náms og 1 námi. Prátt fyrir mikla fræðilega umræðu virðast lýðræðislegir starfshættir ekki hafa átt greiðan aðgang að starfinu í skólastofunum en víst er að kennarar geta haft úrslitavald um pað hvort kennsluhættir peirra stuðli að lýðræðislegri vitund og styrki félagslegt réttlæti í námi (Leach, 2018). Deir bera mesta ábyrgð á pví hvernig námi og kennslu er háttað í kennslustofunni (t.d. Lalas, 2007).

Einn liður í pví að hlúa að lýðræðislegri vitund er efling sjálfræðis ístarfsháttum í skólum. Hugtakið sjálfræði (e. autonomy) í námi má skilgreina pannig að pað séu starfshættir í skólastofunni par sem 
skapað hefur verið svigrúm til að allir aðilar geti tekið ákvarðanir um eigin athafnir (Littlewood, 1999). Sjálfræði í skólastofunni byggist á gildunum ábyrgð (e. responsibility), virðingu (e. respect) og trausti (e. trust), og segja má að pau séu undirstaða starfshátta í skólastofunni sem stuðla að félagslegu réttlæti. Dessi undirliggjandi gildi sjálfræðis geta gegnt pýðingarmiklu hlutverki við að koma til móts við pann fjölbreytta og margmenningarlega hóp sem stundar nám við framhaldsskóla hér á landi. Svo örva megi áhuga og námshæfni nemenda er mikilvægt að peir upplifi að námið sé peirra; að peir geti bæði haft áhrif og völd í eigin námi einir og/eða í samvinnu við aðra nemendur, og um leið sé unnið að próun kennsluhátta (Mitra, 2004). Sýni menntayfirvöld kennurum að peim sé treystandi til að bera ábyrgð á að skipuleggja nám og kennslu og treysti kennari nemendum til að taka frumkvæði í námi er hvorum tveggja sýnd virðing og falin ábyrgð. Gildið traust gegnir pví einnig mikilvægu hlutverki í kennslu sem byggist á sjálfræði.

Markmið pessa hluta rannsóknarinnar var að kanna með vettvangsathugunum hvort og pá hvernig kennarar stuðluðu að sjálfræði með starfsháttum sínum.

Mikilvægt var talið að skoða að hve miklu marki kennsluhættir endurspegla sjálfræði og undirliggjandi gildi pess, ábyrgð, virðingu og traust. Kennsluhættir í framhaldsskólum hafa ekki fyrr verið skoðaðir í pessu skyni og er pví um nýlundu að ræða, sem eykur pekkingu okkar á starfsháttum framhaldsskólans. Eftirfarandi rannsóknarspurning var sett fram:

Hvernig endurspeglast hugtakið sjálfræði og grunngildi pess, virðing, ábyrgð og traust, í starfsháttum og framkomu kennara og nemenda í kennslustofunni?

\section{Grunnhugtök og fræðilegar forsendur}

Í fræðilegum skrifum um raddir nemenda (e. student voice) er talið mikilvægt að hlusta eftir peim pegar efla á lýðræðislega vitund. Degar kennarar hlusta á nemendur, taka tillit til viðhorfa peirra og afstöðu og gefa peim eitthvert val um verklag eykst sjálfræði peirra og samfara pví eflist lýðræðisleg vitund peirra og námsárangur batnar (Fielding, 2004a, 2004b; Mitra, 2004). Með framkomu sinni við nemendur getur kennarinn skapað gagnkvæma virðingu í hópnum milli sín og nemenda, verið peim fyrirmynd og hvatt til virðingar meðal nemenda innbyrðis. Með vali á aðferðum geta kennarar veitt bæði persónulegan og kennslufræðilegan stuðning sem miðar að pví að próa aukið sjálfræði og ábyrgð nemenda (Stefanou, Perencevich, DiCintio og Turner, 2004). En hvað er átt við með hugtakinu sjálfræði í námi og kennslu? Ryan og Deci (2000) skilgreina sjálfræði sem athöfn sem einstaklingur velur sér og hann ber ábyrgð á. Benson (2013) skilgreinir sjálfræði sem hæfnina til að geta stýrt (e. control) eigin námi. Í kennslufræðilegu samhengi er litið svo á að gagnkvæm virðing og ábyrgð sé nauðsynleg forsenda pess að sjálfræði virki eins og til er ætlast. Sem dæmi birtist virðing kennara fyrir nemendum í pví að peir virða skoðanir nemenda, laða fram afstöðu peirra og taka tillit til álits peirra í umfjöllun um mál. Dannig ýta peir undir sjálfstæða hugsun nemenda (sjálfræði) og um leið ábyrgð peirra á pví sem peir segja og gera. Annað dæmi um virðingu kennara fyrir nemendum birtist í pví að efla sjálfræði peirra með pví að leyfa peim að hafa eitthvað að segja um efnisval og aðferðir og treysta pví að nemendur séu færir um að taka á sig pá ábyrgð sem í pví felst. Pannig samtvinnast gildin virðing, ábyrgð og traust pegar efla á sjálfræði í námi.

Í pessari grein er fjallað um kennslufræðilegt sjálfræði og undirliggjandi gildi pess, virðingu og ábyrgð og gagnkvæmt traust, sem pátt í að koma til móts við ólíka nemendur og nemendahópa og gefa peim með pví aukin áhrif í eigin námi. Hér skal bent á að kennslufræðilegt sjálfræði felur í sér bæði kennarasjálfræði og nemendasjálfræði. 


\section{Kennarasjálfrææði}

Dví hefur verið haldið fram að forsenda pess að próa sjálfræði meðal nemenda sé að próa sjálfræði meðal kennara (Little, 1995; Pelletier og Sharp, 2009). Hugtök eins og hæfni, frelsi og ábyrgð hafa verið talin forsenda kennarasjálfræðis. Ýmsir fræðimenn hafa bent á að kennarasjálfræði útheimti að kennarinn búi yfir hæfni, frelsi og ábyrgð til að geta ákveðið hvernig hann eða hún hagar kennslu sinni (Parker, 2015).

Smith (2003) leitar í smiðju ýmissa fræðimanna og dregur saman pað sem hann telur að einkenni kennarasjálfræði. Hann telur að kennarasjálfræði felist í hæfni til að geta tekið frumkvæði, tekið á sig mikla persónulega ábyrgð og stundað stöðuga ígrundun og greiningu á eigin kennslu. Kennarasjálfræði felst einnig í pví að geta ráđið för í eigin starfspróun. Í pví sambandi hefur Bernstein (2000) fjallað um kennslufræðilegan rétt kennarans (e. pedagogical right) og haldið pví fram að sérhver kennari eigi að hafa rétt til að vaxa í starfi. Вað purfi að skapa honum svigrúm til próunarstarfs og símenntunar. Kennari purfi að njóta sjálfræðis innan kerfisins, vitsmunalegs, menningarlegs og persónulegs. Hann purfi að hafa frelsi til að velja viðfangsefni og kennsluhætti og ákveða hvernig árangur er metinn. Enn fremur telur Bernstein að kennarinn purfi að eiga rétt á að taka pátt í uppbyggingu og próun ytri og innri pátta menntakerfisins. Đað geti til dæmis falist 1 að hafa bein áhrif á námskrá.

Bent hefur verið á að til að kennarar geti notið viðurkenningar sem fagfólk með peirri valdeflingu sem pví fylgir purfi peir að hafa frelsi til að vinna samkvæmt eigin hugmyndum og starfskenningu og á pann hátt sem peir telja að komi flestum nemendum til góða (Parker, 2015). Skott (2014) telur að pó að skilgreiningar á starfskenningum kennara fari ekki að öllu leyti saman séu fjórir lykilpættir sem pær eigi sameiginlega:

- Dær vísi til hugmynda sem einstaklingur trúir á

- Í peim sé bæði vitsmunaleg og tilfinningaleg vídd

- Dær séu stöđugar og hafi mótast af félagslegri reynslu

- Dær hafi áhrif á starfið

Í umræðu um starfskenningu fagkennarans hefur verið bent á að hún sé persónubundin og byggist á siðferðilegum gildum, auk pess sem hún hafi vitsmunalega og tilfinningalega vídd (Hafdís Ingvarsdóttir, 2014). Hún telur aftur á móti, gagnstætt Skott (2014), að starfskenningin sé ekki stöđug heldur geti hún próast í ljósi reynslunnar, ekki síst ef kennarar ígrunda kennslu sína. Ef kennari parf að ganga gegn starfskenningu sinni, t.d. vegna einhliða fyrirskipana að ofan, er hætt við að kennsla hans verði hugmyndasnauðari og óskilvirkari (Hafdís Ingvarsdóttir, 2006; Pearson og Moomaw, 2005). Allt petta parf að hafa í huga í umræðunni um breytingastarf og eflingu sjálfræðis í kennslustofunni.

\section{Nemendasjálfrææi}

Ýmsar skilgreiningar eru til á hugtakinu nemendasjálfrææi. Dær eiga pað sameiginlegt að vísa til pess að nemendur setji sér markmið og beri ábyrgð á eigin námi (Little, 1995). Steinunn Gestsdóttir (2012) hefur fjallað um sjálfstjórn unglinga sem tengist að nokkru leyti hugtakinu sjálfræði. Hún telur að meðvituð sjálfstjórnun (e. intentional self-regulation) hjálpi nemendum að forgangsraða markmiðum, og fylgjast með hvernig peim gengur að ná peim markmiðum sem peir hafa sett sér. Hvorutveggja má telja til sjálfræðis. Little $(1991 ; 1995)$ hefur fjallað mikið um hugtakið kennslufræðilegt sjálfræði. Hann segir að prátt fyrir ýmsa fleti á hugtakinu sé engu að síður almennt viðurkennt að nemandi sem nýtur sjálfræðis sé nemandi sem tekur ábyrgð á námi sínu, á frumkvæði að pví að skipuleggja og framkvæma námsverkefni, tekur pátt í að setja sér námsmarkmið og metur skilvirkni eigin náms. 
Af pessu má sjá að hugtökin virðing og ábyrgð eru nátengd sjálfræði. Kennari sem vill deila ábyrgð námsins með nemendum sínum parf auk pess að bera fullt traust til nemenda. Í umfjöllun um sjálfræði tengja Niemiec og Ryan (2009) pað við aukna innri námshvöt og tala um tilteknar gerðir sjálfræðis (e. autonomous types). Deir telja að til að efla nemendasjálfræði purfi að gefa nemendum val og rökstyðja hvers vegna verið er að vinna með tiltekin verkefni. Ekki síst purfi að viðurkenna tilfinningar nemenda gagnvart pessum verkefnum og draga úr prýstingi og eftirliti. Detta gildi ekki síst í hópum par sem nemendur hafa ólíkan menningarlegan bakgrunn.

Black og Deci (2000) hafa fjallað talsvert um nemendasjálfræði og setja fram hugmyndir um hvernig megi smám saman auka sjálfræði nemenda. Deir ræða í pví sambandi um sjálfræði með stuðningi (e. supporting autonomy). Með pví er átt við að kennarinn hlusti eftir viðhorfum nemenda, taki tillit til tilfinninga peirra og veiti nauðsynlegar upplýsingar svo að nemandinn hafi forsendur til að velja. Slíkir kennarar leita eftir viðhorfum nemenda, fella hugmyndir peirra og tilfinningar að starfinu í kennslustofunni. Kennarar sem aftur á móti aðhyllast miðstýrða kennslu reyna að prýsta nemendum til að hugsa og vinna á ákveðinn hátt sem kennarinn stýrir alfarið (Reeve, 2009).

Stefanou og samstarfffólk hennar (2004) hafa útfært pað hvernig megi smám saman vinna að auknu sjálfræði nemenda. Pau benda á að stuðningur við sjálfræði getið farið fram eftir að minnsta kosti premur mismunandi leiðum. Í fyrsta lagi er pað sem pau kalla skipulagssjálfræði og eiga bar við аð nemendur hafi eitthvað аð segja um hvernig skipulagið er í kennslustofunni (e. organizational autonomy). Í öðru lagi er sjálfræði nemenda um pað í hvaða formi peir birta niðurstöður úr verkefnum sínum (e. procedural autonomy). Loks er svo vitsmunalegt sjálfræði (e. cognitive autonomy) sem vísar til pess að nemendur meta vinnu sína út frá viðmiðum sem peir hafa sjálfir lagt til. Dessar leiðir sjálfræðis gefa nemendum ekki eins frjálsar hendur og almennt er gert ráð fyrir en geta verið hentugar fyrir kennara og nemendur sem eru að fikra sig áfram í átt til aukins sjálfræðis.

Ein mikilvæg forsenda pess að nemendur geti tekist á við sjálfræði í námi er að unnið sé markvisst með námsaðferðir (e. learner strategies). Rætt sé við nemendur um námsaðferðir og peim leiðbeint um fjölbreyttar leiðir til að tileinka sér ákveðna pekkingu (Cohen og Macaro, 2007; Hafdís Ingvarsdóttir, 2007; Chamot og Harris, í prentun). Meginmarkmið pess að kenna námsaðferðir er að efla sjálfræði nemandans með pví að hjálpa honum að gera sér grein fyrir pví hvernig hann sem einstaklingur lærir best. Hlutverk kennara er að gera nemandann meðvitaðan um eigin námsaðferðir (e. metacognitive awareness) og um leið hjálpa honum við að fjölga peim aðferðum sem hann getur nýtt sér. Detta gildir ekki síst um nemendur sem koma úr annarri skólamenningu.

Sjálfræði og pau gildi sem kennslufræðilegt sjálfræði byggist á, p.e. virðing, ábyrgð og traust, eru mikilvægar vörður á leið til aukins jöfnuðar í kennslustofunni. Hver nemandi getur unnið út frá eigin forsendum einn og/eða í samvinnu við aðra nemendur. Dað er hins vegar vandasamt að skipuleggja kennslu sem stuðlar að sjálfræði. Til pess parf kennarinn sjálfur að njóta sjálfræðis, hann parf að skilja pau gildi sem að baki liggja og pað frelsi sem pví fylgir (Pelletier og Sharp, 2009). Menning skólans kann par að skipta máli, bæði kennslumenning og samstarfsmenning. Íslenskar rannsóknir benda til pess að samstarfsmenning í framhaldsskólum sé ekki mjög próuð meðal kennara og par ríki jafnvel pögul menning, p.e. ekki sé rætt um starfskenningar hvers og eins og menn forðist faglegan ágreining (Hafdís Ingvarsdóttir, 2014). Samvinnan einkennist fyrst og fremst af pví sem Lortie (1975) kallar tæknilegt samstarf, p.e. að pað felist í pví að neglt sé niður námsefni, yfirferð pess og hvernig skuli meta árangur. Slík samstarfmenning getur verið hindrun í próun sjálfræðis bæði kennara og nemenda. Til að efla sjálfræði parf kennarinn að ráða yfir leiðum og njóta frelsis til að skipuleggja kennsluna pannig að hver nemandi njóti sín. 


\section{Staðan á Íslandi}

Íslenskir framhaldsskólakennarar hafa löngum notið meira formlegs sjálfræðis en mörg starfssystkini peirra í nálægum löndum. Sjálfræði peirra felst meðal annars í pví að algengast er að hver eining, t.d. fagdeild, hafi val um inntak námsins og námsmat. Mætti ef til vill kalla petta sjálfrææi hópsins. Samkvæmt hefð á Íslandi ber hver kennari ábyrgð á pví hvernig starfinu í kennslustofunni er háttað. Enn fremur ber hver kennari ábyrgð á eigin starfspróun. Íslenskir framhaldsskólakennarar njóta pannig sjálfræðis í orði kveðnu. Ef hugur peirra og hæfni stendur til pess eru peir í raun frjálsir að pví að haga innra skipulagi og inntaki kennslunnar pannig að pað stuðli að sjálfræði nemenda og virki sköpunarmátt og efli samvinnu, eða eins og stendur í gildandi aðalnámskrá:

Samkvæmt lögum um framhaldsskóla nr. 92/2008, færist ábyrgð á námskrárgerð í auknum mæli til framhaldsskólanna. Deim er nú falið að gera tillögur um fyrirkomulag, samhengi og inntak náms í samræmi við viðmið, sniðmát og reglur um gerð námsbrautarlýsinga.... Detta skipulag á jafnframt að veita skólum tækifæri til að bregðast markvisst við pörfum nemenda, samfélags og atvinnulífs, niðurstöðum rannsókna og gæðaeftirlits (Aðalnámskrá framhaldsskóla, 2011).

Í gildandi aðalnámskrá (2011) er eingöngu rætt um skólana sem stofnun en ekki stjórnendur og kennara sérstaklega eða hlutverkaskiptingu peirra, að undanskildum kaflanum um námsmat. Skólar eða stjórnendur og kennarar, sem væntanlega eru sérmenntaðir fagkennarar, hafa val um pað hvernig haga skuli náminu svo að tiltekin hæfni náist. Túlka má námskrána pannig að pað sé hverjum skóla og pá hverjum kennara í sjálfsvald sett hvort hann eflir sjálfræði meðal nemenda sinna og eykur ábyrgð peirra í námi. Bá vaknar spurningin hversu vel kennarar eru undirbúnir og hversu markvissa menntun peir hafa fengið til að starfa á pennan hátt. Einnig skiptir hér máli hversu vel pessar hugmyndir samræmast starfskenningum peirra um eigið hlutverk í kennslustofunni. Fræðimenn, bæði erlendir og innlendir, sem rannsakað hafa sjálfræði kennara, telja að ein helsta hindrunin sé ótti peirra við að sleppa taumhaldinu ef nemendur fá meira sjálfræði (sjá til dæmis Dam, 1995; Hjördísi Dorgeirsdóttur, 2018). Enn fremur má vísa til nýlegrar rannsóknar á starfi grunnskólakennara, en par benda niðurstöður til pess að kennarar hneigist til að bregðast við áhugaleysi nemenda með aukinni stýringu, og megi rekja pað til gilda og afstöðu kennarans (Ingibjörg Kaldalóns, 2017). Simon Borg, sem um langt skeið hefur rannsakað hugmyndir kennara og áhrif peirra á starfið, segir að viðurkenna purfi að hugmyndir kennara hafi bæði áhrif á pað hvernig peir læra og hvað peir gera (Borg og Alshumaimeri, 2017) og samkvæmt pví purfi að fá fram og vinna með hugmyndir kennara bæði í grunnnámi og símenntun.

Rannsókninni sem hér verður fjallað um er ætlað að auka pekkingu okkar á kennsluháttum í framhaldsskólum, einkum með tilliti til áhrifa nemenda á nám sitt. Niðurstöður hennar ættu að geta vísað veginn til frekari skólapróunar í framhaldsskólum.

\section{Rannsóknin}

Dessi athugun er hluti af rannsóknarverkefninu Starfsháttum í framhaldsskólum sem fram fór í níu framhaldsskólum víðsvegar um landið og voru valdir sem lagskipt slembiúrtak með hliðsjón af landshlutum, stærð skóla og gerð peirra, auk pess sem pess var gætt að í úrtakinu lentu skólar sem væru annaðhvort nýir eða hefðu mikið breyst á undanförnum árum [^]. Til að fá fram pá vitneskju sem sóst var eftir hér, p.e. að hve miklu leyti hugtakið sjálfræði og undirliggjandi gildi, virðing, ábyrgð og traust, einkenndu starfshætti í pessum níu framhaldsskólum, voru notaðar vettvangsathuganir og eru vettvangsnótur lagðar til grundvallar.

Í rannsókninni var 45 bekkjum eða einstökum nemendum í áfangaskólum fylgt eftir í einn skóladag (án pess pó að viðkomandi nemandi vissi af pví). Alls voru skráðar 130 vettvangslýsingar 
1 bóklegum og verklegum tímum (flestar 40-80 mínútna langar). Athugendur skrádu vettvangsnótur jafnóðum. Ýmist voru pær slegnar beint inn á tölvu eða handskrifaðar og slegnar inn við fyrstu hentugleika. Tveir athugendur sátu 44\% kennslustundanna og skráði hvor um sig sína vettvangsathugun. Að pví loknu báru peir saman bækur sínar og skrifuðu ýmist saman lokaeintak eða annar skrifaði og hinn las yfir og gerði athugasemdir ef purfa pótti. Markmiðið með pví að hafa tvo rannsakendur var að auka réttmæti athugananna (e. interrater validity).

Í öllum tilvikum var pað sem gerðist í kennslustundinni skráð skipulega en í framhaldinu drógu athugendur saman pað sem kallað var „tíminn í hnotskurn“. Loks var reitur sem var kallaður „athugasemdir rannsakenda“. Dar lýstu athugendur pví hvernig peir höfðu skynjað tímann, t.d. hlutverk og samskipti nemenda innbyrðis og samskipti nemenda og kennara. Dað eru pessir tveir síðastnefndu pættir, pað er tíminn í hnotskurn og athugasemdir rannsakenda, sem eru pau megingögn sem nýtt eru í pessari grein, og mikilvægt er að taka fram að pað er upplifun og túlkun rannsakenda á kennslustundinni sem lögð er til grundvallar greiningunni. Dessir tveir dálkar voru marglesnir með hliðsjón af kenningum um kennslufræðilegt sjálfræði (ábyrgð, virðing og traust) til að fá fram flokka (e. categories) (Miles og Huberman, 1994). Flokkunum er raðað frá eitt til fimm eftir pví að hve miklu leyti nemendur nutu sjálfræðis við námið í kennslustundinni. Í flokk eitt fóru pær athuganir sem sýndu algera kennarastýringu og í flokki fimm eru dæmi um pað pegar nemendur höfðu engan ramma annan en lengd kennslustundarinnar, og hinir flokkarnir voru parna á milli. Degar flokkarnir voru fram komnir voru nákvæmar vettvangslýsingarnar á kennslustundinni yfirfarnar og hafðar til hliðsjónar við endanlega yfirferð greiningarinnar og gegndi sá yfirlestur hlutverki margprófunar (Patton, 1994). Loks voru valin eitt til prjú sýnidæmi; eitt sýnidæmi par sem sáust fæst dæmi og prjú par sem dæmin voru flest sem einkenndu flokkinn. Tíminn í hnotskurn og athugasemdir rannsakenda eru sameinuð í textanum í sýnidæmunum. Til að dylja kennara betur (en trúnaði hafði verið heitið) er á stöku stað skipt um orð, til dæmis notað markmál í erlendu málunum í stað pess að segja hvert tungumálið er.

\section{Skyggnst inn í kennslustofur}

Í pessum hluta verður skyggnst inn í kennslustofurnar. Hér verða sýndar orðréttar umsagnir athugenda úr hverjum flokki; athuga ber að fornöfnin ég eða við í vettvangsnótum vísa til athugenda. Flokkarnir sem fram komu eru eftirfarandi: Miðstýrð kennsla, prófastýring, viðleitni og virðing, í átt til sjálfræðis, nemendasjálfræði í verki. Hver flokkur er ræddur í ljósi kenninga um kennslufræðilegt sjálfræði og peirra gilda sem að baki liggja. Mikilvægt er að hafa í huga að hér er ekki verið að leggja dóm á kennsluhættina heldur einungis spegla kennsluna í ljósi pess að hve miklu marki nemendur nutu sjálfræðis í kennslustundinni. Einnig skal tekið fram að algengast er að vettvangsathugun taki aðeins til einnar kennslustundar hjá hverjum kennara.

\section{Miðstýrð kennsla}

Kennslustundir sem einkenndust af miðstýrðri kennslu voru mest áberandi af peim mikla fjölda kennslustunda sem fylgst var með. Hér eru tekin prjú dæmi til að sýna að kennslustundirnar voru ólíkar en áttu pað sameiginlegt að vera alfarið skipulagðar af kennara. Nemendum var ekki falin ábyrgð á neinum hluta stundarinnar né fengu peir tækifæri til að hafa áhrif á pað sem fram fór. 


\section{Sýnidæmi 1}

Viðfangsefni kennslustundarinnar var islam (lokapunktur aftan við umfjöllun) og víkingatíminn með sérstakri áherslu á landnám Íslands. Í byrjun var farið yfir svör við síðasta verkefni, pá var fyrirlestur [kennara] og loks var lagt fyrir annað verkefni sem farið verður yfir í upphafi næsta tíma - petta virðist fast vinnulag. Nemendur tóku pátt í pessu eftir smekk og behag. Algerlega kennarastýrð kennsla, lítið óskað eftir framlagi nemenda. Vel tekið í spurningar peirra en aldrei reynt að kveikja umræður í kennslustofunni. Mikið talað um landafræði víkingatímans o.s.frv. án pess pó að nota landakort, t.d. af netinu (en kveikt var á tölvu og skjávarpa megnið af tímanum). Pó að kennarinn gengi á milli eftir að nemendur fóru að vinna verkefni skipti hann sér ekki af tölvunotkun, símanotkun eða svefni pilts sem dottaði á áberandi hátt. Kennari virtist ópvingaður og vinsamlegur í garð nemenda, var t.d. í gódu augnsambandi við hópinn á meðan hann flutti fyrirlestur, en furðu áhugalaus um skoðanir nemenda. Pegar stúlka kvaðst hafa séð sjónvarpspætti sem kennari nefndi greip hann til dæmis ekki pann umræðupráð frekar en aðra.

\section{Sýnidæmi 2}

. Nemendur unnu verkefni í tölvum sínum. Verkefnið hafði verið lagt inn á Moodle og virtist snúast um að leita í kennslubók og glærum að réttum svörum. Petta var verkefni sex af núu. Viðfangsefnið var kafli 11 í bókinni. ... Viðfangsefni tímans virtist helst pjálfa nemendur í að finna rétt svör í bókinni og skrifa pau upp, einhverjir skiptu spurningum á milli sín og afrituðu svörin 1 gegnum Facebook. Tækifæri til að virkja nemendur voru ekki nýtt. Engin markviss umræða fór fram, ekki pjálfun í gagnrýninni hugsun, að setja hlutina í samhengi eða neitt slíkt. Engin vinna var með grunnpætti. Kennarinn sýndi nemendum lítinn sem engan áhuga og horfði sjaldan upp frá sínum eigin tölvuskjá. Ef nemendur spurðu kennarann að einhverju (sem gerðist reyndar sjaldan) svaraði hann peim alltaf mjög stuttlega úr sæti sínu og gekk ekki á milli. ... Kennarinn gaf nemendum ekki fyrirmæli önnur en pau að nýtt verkefni væri komið inn á Moodle og pau fengju pennan tíma til að skoða pað. Pau fóru fljótlega öll að vinna í verkefninu og virtust vera vön pessu vinnulagi.

\section{Sýnidæmi 3}

... Kennarinn var í miðlunarhlutverki með beinni einhliða kennslu par sem hún las upp texta og
svaraði sjálf en virkjaði pó nemendur annað slagið með spurningum um stök orð og pá aðallega
prjá nema af 16. Stúlkurnar í tímanum voru afar óvirkar og höfðu ekki rödd í kennslustundinni
prátt fyrir veika tilraun til pess. Nemendur voru flestir óvirkir og í öðrum verkum í tölvunni eða
símanum. Par voru helst Facebook, tónlist og leikir sem réðu ferðinni. Í lokin voru nemendur
virkjaðir í einstaklingsvinnu við pað að svara spurningum sem kennarinn fyllti jafnóðum inn
í á töflunni og beið ekki endilega eftir svari. Viðmót kennarans í garð nemenda einkenndist
af hlýleika og mikilli alúð. Kennarinn átti pó erfitt með að losa tökin (reyndi ekki) og treysta
hópnum.

Kennslustundin einkenndist af mikilli mötun og lítilli yfirsýn kennarans á virkni nemenda. Stúlkurnar í tímanum fengu enga athygli og netnotkun var algjörlega stjórnlaus. Kennarinn átti afar erfitt með að treysta nemendum og stýrði verkefnum peirra í góðri trú og í móðurlegum tilgangi, eins og hún lýsti sjálf... Nemendur áfangans voru ansi slungnir að leika á kennarann, sýndu henni bara pað sem peir gerðu eða voru búnir að loka tölvunni til að fela óvirkni sína.... Nemendur purftu ekkert að tjá sig á markmálinu (áttu bara að vera að læra glósur) og kennarinn notaði markmálið ekkert til samskipta og lítið til skýringa, nær eingöngu til upplestrar af skjá. Við veltum líka fyrir okkur hvernig próf eru notuð sem agatæki [kennarinn lagði áherslu á að pað yrðu próf úr pessu í næstu viku]. Við veltum pví jafnframt fyrir okkur hvort ekki purfi að 
höfða til fjölbreytts áhuga nemenda, og hvers vegna allir purftu að lesa sama textann. Hvað með lýðræðisleg vinnubrögð og rödd og framlag nemenda, sköpun og annað sem aðalnámskrá boðar?

Dessar prjár kennslustundir eru um margt ólíkar en ef pær eru skoðaðar í ljósi sjálfræðis er ljóst аð pær eiga pað sameiginlegt að ekki er um slíkt að ræða. Раð sem líka einkennir dæmin er að hvorki er gerð tilraun til að virkja nemendur né örva áhuga peirra á viðfangsefninu. Nemendum er ekki falin ábyrgð og peir hafa ekkert um námsefnið að segja eða úrvinnslu pess. Mikið skortir pví á að vinnubrögð séu lýðræðisleg eða að nemendum sé gefin rödd (Fielding, 2004a; Mitra, 2004). Framkoma kennara var pó ólík. Í dæmum 1 og 3 er kennari vinsamlegur og í dæmi 1 virðist hann vera í nokkuð góðu sambandi við hópinn.

\section{Prófastýring}

Annað dæmi um kennarastýringu, sem er nokkuð annars eðlis, er skyndiprófin. Par sem skyndipróf virðast skipa stóran sess í skólastarfinu pótti mikilvægt að taka dæmi af miklum áherslum á skyndipróf sem við urðum vör við í nær öllum skólum. Bæði var petta ljóst af spurningum sem nemendur beindu sífellt til kennara: Hvenær er næsta próf? Eða: Verður prófað úr pessu? Og: Hvenær fáum við prófið til baka? Dæmi voru um heilu tímana sem var varið í undirbúning nemenda fyrir skyndipróf sem giltu mismikið (án samráðs við nemendur). Hér verða tekin tvö dæmi um slíkar kennslustundir.

\section{Sýnidæmi 4}

Efnið er raungrein skv. námskrá og nemendur eru að búa sig undir próf morgundagsins, sem gildir 10\%. Stundin er vinnustund par sem hver nemandi vinnur fyrir sig pótt viss samskipti séu á milli nemenda. Efnið virðist vera á tölvu en nemendur nota líka glósur og sumir lesa pær í gríð og erg. Kennslan felst alfarið í pví að kennari gengur á milli nemenda og ræðir við pá eftir pví sem peir kalla eftir. Hann gaf sér góðan tíma með hverjum og einum. Tölvan var stýrandi afl í kennslustundinni og par af leiðandi voru lítil samskipti nemenda á milli. Allt efni áfangans var á netinu og pví mikið einstaklingsframlag og nemendur pví misvirkir. Deir voru ýmist að útbúa glósur eða að svara spurningum í tölvunni. Kennarinn gekk á milli nemenda og aðstoðaði pá eftir pörfum en pó eingöngu pá sem báru sig eftir björginni. Nokkur notkun samfélagsmiðla var áberandi. Kennarinn var vinalegur en gaf ekki mikið af sér.

\section{Sýnidæmi 5}

Kennsluaðferðin er að nemendur pýða orð úr glósulista sem kennari hefur útbúið. Detta eru orð úr greinum úr greinahefti (sem kennari hefur valið) og ekki er að sjá að pað sé neitt kerfi í orðavalinu. Ekki er ljóst hvernig eða hvort búið er að vinna með greinarnar áður, t.d. innihald. Nemendur eru lúsiðnir, sitja og glósa enda er yfirvofandi próf í pessum glósum. Nemendur nota orðabækur (sem eru til staðar í stofunni), tölvur eða snjallsíma til að finna orðin. Dað vekur athygli hversu ópersónulegur, daufur en samt kurteis kennarinn er og hversu lítinn áhuga hann sýnir nemendum og verkefnum peirra. Hann gengur aldrei um til að skoða hvernig gangi og ræðir ekkert um hvernig sé best að læra ný orð (virðist ekki hafa gert pað áður miðað við vinnubrögð í tímanum). Hann skiptir sér heldur ekkert af pótt pau séu noti ekki samhengi í sögunum til ad skilja orðin og hvetur pau ekki til pess. ... Рað vekur líka athygli hversu vinnusamir nemendur eru (bótt deila megi um gagnsemi vinnunnar). Væntanlegt próf virðist vera mjög sterk hvatning. Einu spurningarnar sem bornar voru fram tengdust væntanlegu prófi.

Svo virðist sem skyndipróf séu í ríkum mæli notuð sem aga- og kennslutæki. Pótt hér séu aðeins tekin tvö dæmi bar skyndipróf á góma í fjölda kennslustunda. Prófin eru samin af kennurum og metin af kennurum. Detta virðist vera leið sem beitt er til að fá nemendur til að tileinka sér tiltekið 
námsefni. Eins og dæmin hér að framan sýna var jafnvel heilum kennslustundum varið í að gefa nemendum tækifæri til að undirbúa sig fyrir próf. Í kjölfarið er svo annarri kennslustund eða hluta hennar varið í að preyta prófið. Niemiec og Ryan (2009) telja að til að efla sjálfræði purfi ekki síst að viðurkenna tilfinningar nemenda gagnvart verkefnum sínum og draga úr prýstingi og eftirliti. Prófamiðuð kennsla eins og sú sem við sáum vinnur pví gegn sjálfræði nemenda par sem einn páttur í pví er að nemendur hafi eitthvað að segja um námsmat.

Ekki sást tilraun til að efla námsáhuga nemenda með pví að gefa peim tækifæri til að hafa áhrif á matið, hvorki við gerð matsverkefnis né við mat. Samkvæmt gögnunum kom ekki fram að símat eða leiðsagnarmat væri iðkað. Í einum skóla var rætt um að notað væri leiðsagnarmat. Sumir kennarar vildu skilgreina pessi stöðugu skyndipróf sem símat. Símat og leiðsagnarmat eru hvorutveggja andstæða lokaprófs. Áherslan í símati er á ferlið fremur en útkomuna (sjá til dæmis Le Grange og Reddy, 2000). Dað felst pví ekki í stökum pekkingarprófum úr tilteknu námsefni eins og virtist einkenna pau skyndipróf sem við urðum vör við. Með símati er oftast átt við að ferli og árangur nemandans er skoðað heildrænt, öll verkefni og skyndipróf sem unnin hafa verið yfir önnina koma til lokaeinkunnar. Leiðsagnarmat er hins vegar mikilvægur páttur í að efla stuðning við nemandann (Hattie og Timperley, 2007) og um leið stuðla að auknu sjálfræði, en par er áherslan á ferlið og samræður kennara og nemenda par sem neminn leggur mat á eigin verk í samræðum við kennara.

\section{Viðleitni og virðing}

Margar kennslustundir sýndu viðleitni kennara til að virkja nemendur og gera námið áhugavert pótt ekki væri hægt að tala um sjálfræði samkvæmt skilgreiningu. Engu að síður geta slíkar kennslustundir verið áfangi á leið til sjálfræðis. Sýnd verða dæmi um pær kennslustundir par sem viðleitni í átt til sjálfræðis og um leið gagnkvæm virðing komu fram. Fjallað verður um pær hvora í sínu lagi par sem pær voru talsvert ólíkar.

\section{Sýnidæmi 6}

Kennslustundin var mjög vel skipulögð og andrúmsloft notalegt og mjög líflegt. Markmálið var áberandi mikið notað af kennaranum en einnig nemendum. Kennarinn var hvetjandi, pekkti nemendur vel, náði vel til peirra og hafði góða yfirsýn. Hún notar líkamann afar mikið til аð virkja nemendur, t.d. með hvetjandi og ögrandi framkomu, handabendingum og smellir fingrum ótt og títt. Mikið var lagt upp úr virkni nemenda og peir virkjaðir stöðugt. Áhersla var á munnlega tjáningu. Kennarinn var að rifja upp málfræði ... Hún byrjaði á að láta pau æfa strúktúrinn [munnlega]. Eftirtektarvert var hvernig hún kom alltaf með dæmi sem gætu höfðað til nemenda (t.d. ég fór í bío um helgina). Hún rifjaði upp reglurnar með aðstoð nemenda og notaði/benti á veggspjöldin sem nemendur höfðu unnið. Hún hafði sama háttinn á með seinni flokk sagnanna. Tímanum lauk með pví að fjórir drengir (tvö pör) voru með tvo örfyrirlestra um sjálfvalið efni og voru með punkta sér til stuðnings og myndir á glærum.

Kennslustundin einkenndist af mikilli virkni nemenda. Uppröðun í stofunni hjálpaði til [uuppröðun] svo og látlausar spurningar kennara, hvatning og hrós. Dessi stofa sýndi hvað fagstofa getur skipt miklu máli ef hún er nýtt sem slík. Veggir voru vel skreyttir með veggspjöldum nemenda sem mikið voru notuð í kennslunni. Рað var áberandi hvað kennarinn hafði tungumálið vel á valdi sínu og fléttaði markmálinu og íslensku listilega saman. Henni tókst að endurtaka sífellt án pess að pað yrði leiðigjarnt eða virkaði sem slíkt. Hún hvetur nemendur augljóslega til sköpunar og virkjar áhugamál peirra. Hún virtist átta sig mjög vel á stöðu nemenda og tengdist peim vel. Mjög athyglisvert var að sjá hvernig hún vann með námsaðferðir (e. learner strategies). Hún kom fram við nemendur af virðingu og peir sýndu henni líka virðingu og hver öðrum. Augljóst var að henni er gagnkvæm virðing og virkni hugleikin. 
Aðeins einn pátt í pessari kennslustund má flokka undir hreint nemendasjálfræði samkvæmt skilgreiningu, en pað var sjálfvalið efni sem nemendur fluttu og höfðu peir val um tilhögun flutnings. Á veggjum stofunnar hanga veggspjöld með málfræðireglum sem nemendur hafa sjálfir útbúið (að ósk kennara). Nemendur eru sjálfir látnir búa til setningar til að æfa málfræðiatriðin. Deir mynda pví setningar par sem peir nýta pann orðaforða sem hver um sig hefur yfir að ráða. Darna var dæmi um kennslustund par sem augljóslega var verið að vinna markvisst með námsaðferðir sem eru ein forsenda sjálfræðis (samanber umfjöllun hér að framan). Síðast en ekki síst var áberandi hversu mikil virðing ríkti í stundinni milli kennara og nemenda og nemenda á milli.

\section{Sýnidæmi 7}

Unnið var með mismunandi greinar sem nemendur áttu að hafa lesið fyrir tímann. Kennarinn valdi greinarnar og setti inn í kennslukerfið. Fyrirfram vissu nemendur að petta verkefni gæfi eitt stig í einkunnavægi. Greinarnar eru til pess hugsaðar að vekja nemendur til umhugsunar um ákveðin málefni og fá pá til að mynda sér skoðun um leið og peir tileinka sér og læra að nota nýjan orðaforða. Nemendur völdu sér grein út frá áhugasviði og unnu í hópum með orðaforða úr greinunum. Peir völdu fimm orð úr hverri grein og bjuggu til fimm setningar par sem í hverri setningu var eitt af pessum orðum. Degar leið á tímann var hópunum skipt upp í minni hópa (pör). Verkefnið var unnið í tölvu og voru spjaldtölvur notaðar til pess að fletta upp orðum. Hver hópur mátti aðeins nota eina tölvu en pegar hópunum var skipt upp máttu pau nota tvær tölvur. Kennarinn gekk á milli hópa og hvatti nemendur áfram og gekk úr skugga um að allir skildu verkefnið. Degar hóparnir voru um pað bil að ljúka settist hún hjá hverjum hópi og ræddi við pau. Kennarinn var glaðlegur og hvetjandi og andrúmsloftið var notalegt. Kennari talaði markmálið allan tímann og nemendur svöruðu yfirleitt á markmálinu en töluðu mestmegnis saman á íslensku í hópunum. Í lok kennslustundarinnar var hver hópur látinn tjá sig um pað hvernig peim líkaði verkefnið og hvort pað hefði verið of létt eða of pungt.

Í dæmi tvö má einnig sjá hugmyndir sem rekja má til nemendasjálfræðis. Nemendur geta valið úr nokkrum fjölda greina eftir áhugasviði (og getu). Verkefni gilda almennt mismarga punkta og er punktafjöldi (vægi) ákveðið í samráði við nemendur. Nemendur eru einnig spurðir álits um verkefnið í lokin. Kennarinn stýrir hins vegar kennslustundinni, greinarnar eru valdar af kennaranum, pað skal vera hópvinna og hún er skipulögð af kennaranum, meðal annars til að tryggja að allir séu virkir. Einnig er ákveðið hvernig verkefnið er unnið. Nemendur ráða hins vegar hverjir vinna saman og hvaða hlutverki peir gegna í hópnum og setningar eru samdar frá grunni af nemendum. Nemendum er falin viss ábyrgð, og gagnkvæm virðing einkenndi kennslustundina.

\section{Í átt til nemendasjálfrææis}

Fjórði flokkurinn sýnir enn eitt skrefið til sjálfræðis. Hér er nemendum gefið enn meira svigrúm og er peim sýnt talsvert traust. Einnig hér er fjallað um pessi dæmi hvort í sínu lagi par sem pau voru að mörgu leyti ólík pótt bæði sýni merki um viðleitni kennara til að veita nemendum ákveðið sjálfræði.

\section{Sýnidæmi 8}

Inntakið var orðaforði og æfing í að skrifa á markmálinu. Aðferðin var hópverkefni. Nemendur áttu að lýsa ferð til ákveðins lands og réðu hvernig peir gerðu pað og hvernig peir skiluðu af sér. Deir fengu mikið frjálsræði innan ramma kennara (sem var mjög rúmur). Skrifleg fyrirmæli kennara um verkefnið voru skýr og án efa hjálpleg en ekki mjög bindandi. Nemendur áttu pess kost að nýta hugmyndaflugið og hafa frumkvæði. Hlutur kennara var fyrst og fremst leiðbeinandi. 
Hún gekk á milli hópa sem voru í stofunni og á bókasafninu og talaði yfirleitt alltaf markmálið. Hún var hlýleg við nemendur og lagði sig fram um að aðstoða pá. Nemendur voru virkir, allir sem ég sá til í stofunni unnu allan tímann að verkefninu. Hópvinnan fólst í pví að nemendur skiptu með sér verkum 1 stað pess að vinna saman. T.d. vann annar hópurinn lýsingu hvor á sínum deginum í ferðinni. Dó voru samræður öðru hvoru um einstaka pætti sem pau voru að skrifa um. Vinnuandi ríkti í stofunni.

Hér birtast ýmsir pættir sem flokka má undir nemendasjálfræði (sbr. Niemiec og Ryan, 2009). Kennarinn ákveður að vísu efnið og kennsluaðferðina en að öðru leyti ráða nemendur ferðinni og hafa val. Deir ráða hvernig peir vinna verkefnið og í hvaða formi peir skila niðurstöðum. Hér fá nemendur tækifæri til að vinna á eigin forsendum og út frá hæfni hvers um sig. Deir geta líka unnið með eigin áhugasvið, gætu til dæmis skipulagt hjólaferð, borgarferð, sumarbústaðarferð. Ekki kom fram hvernig mati væri háttað, t.d. hvort pað væri að einhverju leyti í höndum nemenda. Segja má að pessi leið geti flokkast undir pað sem Black og Deci (2000) nefna sjálfræði með stuðningi.

\section{Sýnidæmi 9}

Verkefni tímans fólst í pví að hver hópur valdi eða fékk úthlutað einum kafla úr bókinni, sem pau áttu að skipta á milli sín og kynna svo fyrir öllum hópnum. Kennarinn hvatti nemendur til að vera frumlegir, syngja, spila, leika o.s.frv. Í upphafi rifjaði kennarinn upp síðasta tíma og kynnti verkefni pessa tíma (10 mín.). Við tók hópvinna nemenda (60 mín.) að átta mismunandi samfélagslegum verkefnum. Nemendur voru allir farnir út 10 mín. ádur en tíma lauk samkvæmt stundaskrá. Kennslustundin einkenndist af miklu frelsi nemenda. Í upphafi tímans fengu peir verkefni sem peir áttu að vinna í hópum, peir gátu nokkurn veginn stjórnað pví hversu mikið peir myndu vinna pað í hópnum og hversu mikið hver út af fyrir sig. Nemendur fengu mikinn sveigjanleika við verkefnið, máttu kynna paðá pann hátt sem peir vildu (kynningin átti að vera í næstu eða parnæstu viku) og máttu nota efni utan bókarinnar ef peir vildu. Kennarinn hvatti nemendur hvað eftir annað til að vera frumlegir í útfærslu verkefnisins. Hún var í góðum samskiptum við nemendur, gekk stöðugt á milli hópanna, spjallaði mikið við pá, talaði mikið yfir hópinn, pótt hún væri að svara einum nemanda, og var tilbúin að aðstoða pá með verkefnið. Dað var mjög mismunandi hversu mikið nemendur voru að vinna í verkefninu og hversu mikil samskipti voru innan hópanna. Í sumum hópum voru samræður um verkefnið nánast allan tíman, en í öðrum hópum nánast engar samræður, heldur voru allir hópmeðlimir að vinna í tölvum (eða í einhverju öðru).

Hér virðist vera um að ræða pað sem Stefanou og félagar (2004) kalla skipulags-sjálfræði, en pau eiga par við аð nemendur hafi eitthvað að segja um hvernig skipulagið er í kennslustofunni, eins og hér má sjá, og í síðara dæminu ráða nemendur alfarið í hvaða formi peir birta útkomu/niðurstöðu verkefna sinna (e. procedural). Aftur á móti er ekki að sjá að um sé að ræða vitsmunalegt sjálfræði samkvæmt kenningu peirra Stefanou og félaga, p.e. að peir eigi sjálfir að meta árangurinn.

\section{Nemendasjálfræði í verki}

Pótt vissulega sæjust dæmi um að unnið væri með hugmyndir nemendasjálfræðis, eins og sést hér að framan, gaf kennarinn par alltaf skýran ramma, en nemendur höfðu svo frjálst val um hvernig skipulagið væri innan rammans. Hér verður að lokum gefið dæmi um vettvangsathugun par sem unnið var með nemendasjálfræði án pessa ramma kennarans. Verkefnið var að skipuleggja og stýra einni kennslustund 1 ípróttum. Hvernig nemendur skiptu með sér verkum við stjórnina, hvaða æfingar eða leiki peir völdu og hvenær og hvaða tónlist var leikin var allt alfarið peirra. Mikilvægt er að taka petta dæmi með til að sýna að slíkar kennslustundir fyrirfinnast. 


\section{Sýnidæmi 10}

Hér voru pað nemendur sem réðu ferðinni alla kennslustundina. Peir höfðu skipt með sér verkum og skipulagt mismunandi æefingar. Раð voru alltaf pör sem stjórnuðu og skiptust á að gefa fyrirskipanir. Æfingar voru mjög fjölbreyttar og reyndu á ólíka pæetti, kraftæfingar, hlaup, boltaleikir og slökun. Kennarinn skipti sér ekki af fyrir utan pað аð hann bauðst einu sinni til að vera stigavörður og bað einu sinni um að tónlist væri lækkuð (í slökuninni). Parna var um hreint sjálfræði nemenda að ræða, peir báru alla ábyrgð á tímanum. Skipulagið var mjög gott og hver æfingin rak aðra og skiptingar gengu ótrúlega hratt fyrir sig. Nemendur voru augljóslega vanir pessum vinnubrögðum og hlýddu hver öðrum nær skilyrðislaust. Peir réðu einnig hvort og hvaða tónlist var notuð. Kennarinn sagði aðspurður að hópstjórarnir pyrftu að skila skriflegri skýrslu par sem peir útskýrðu æfingarnar og markmið peirra. Рað var líka athyglisvert að sjá að petta voru allt æfingar eða leikir sem allir gátu tekið pátt í, burtséð frá líkamsburðum.

Hér er enginn rammi annar en mínútufjöldi stundarinnar. Nemendur setja sér markmið, peir taka fulla ábyrgð á náminu, taka frumkvæðið að pví að skipuleggja og framkvæma námsverkefni og purfa að fjalla skriflega um markmið og skilvirkni (Little, 1995). Ekki var ljóst hvernig mati á skriflega verkefninu var háttað, p.e. hvort nemendur höfðu eitthvað um pað að segja. Рar sem rannsakendur voru ekki í aðstöðu til að skoða skriflegu verkefnin er ekki vitað hvort pau innihéldu einnig ígrundun um stundina, sem hefði verið í anda kenninga um sjálfræði. Kennarinn sýndi nemendum traust og fól peim mikla ábyrgð og nemendur sýndu að peir voru traustsins verðir. Рað vakti einnig athygli hversu fjölbreyttar æefingarnar voru og hvernig hópstjórar skipuðu í hlutverk og gættu pess að allir gerðu æfingar eða tækju pátt í leikjum, sem allir gátu tekið pátt í, hver eftir sinni getu.

Meginniðurstaða vettvangsathugana er að kennarastýrð kennsla skipar háan sess og sjaldan er hlustað eftir röddum nemenda. Petta er prátt fyrir aðalnámskrá par sem skólum og kennurum er falið mikil vald, en ekki er að sjá að pað sé almennt nýtt til að efla markvisst sjálfræði nemenda og gefa peim tækifæri til að fást oftar við verkefnin á eigin forsendum, par sem peir eru staddir í námi hverju sinni og hæfni peirra leyfir.

\section{Samantekt og ályktanir}

Hér að framan var pví haldið fram að til að efla lýðræðislega vitund í skólastarfi pyrfti að beita lýðræðislegum starfsháttum. Ein leið til pess væri að auka nemendasjálfræði og um leið að huga аð kennarasjálfræði (Parker, 2015; Pearson og Moomaw, 2005; Little, 1995). Kennarasjálfræði ætti ekki að standa í vegi hér par sem íslenskir framhaldsskólakennarar njóta mikils formlegs sjálfræðis. Menntamálayfirvöld hafa framselt skólum vald yfir skipulagi náms (Aðalnámskrá, 2011) og námsefni og kennsluhættir eru alfarið í höndum skólanna og jafnvel einstakra kennara eða fagdeilda.

Í athugun á brottfalli kemur fram að námsleiði og áhugaleysi séu meginástæður sem ungmenni á Íslandi gefa fyrir pví að hverfa frá námi í framhaldsskóla (Jón Torfi Jónasson og Kristjana Stella Blöndal, 2002). Í skýrslu OECD frá 2012 (OECD, 2012, bls. 7) er sett fram sú tilgáta að mikið brottfall úr framhaldsskólum skýrist meðal annars af skorti á heppilegu námsefni og of greinabundinni námskrá (e. subject based curriculum). Petta bendir til pess að mikilvægt sé að gefa nemendum tækifæri til að hafa aukin áhrif á eigið nám, hlusta eftir röddum peirra og auka sjálfræði eftir pví sem tök eru á.

Sýnishornin úr gögnunum af hinum ýmsu stigum nemendasjálfræðis sýna samt að margir kennarar kjósa að vinna í anda sjálfræðis og eru að fikra sig áfram í átt til pess að gefa nemendum aukin áhrif. Skýringin á pví hversu útbreidd kennarastýrð kennsla virðist samt vera getur legið í ýmsum páttum, svo sem skólamenningu, hefoum og samstarfi innan skólans (Hafdís 
Ingvarsdóttir, 2014; Goddard og Goddard, 2007; Warren Little, 1990). Dó að í viðtölum við kennara komi fram dæmi um frjótt samstarf hafa rannsóknir gefið vísbendingar um að í sumum framhaldsskólum prífist pað sem kallað hefur verið pögul menning, pað er að kennarar forðist kennslufræðilegan ágreining og faglegar rökræður (Hafdís Ingvarsdóttir, 2014). Sé pað almennt parf að vinna í skólunum að pví sem Fullan og Hargreaves (2016) kalla faglega samstarfsmenningu (e. culture of collaborative professionalism) sem parf pá að ýta undir og próa frekar. Hugsanlegt er einnig að missterkar hefðir kennslugreina geti haft parna áhrif (Wideen, 1994; Valgerður S. Bjarnadóttir, í pessu sérrriti). Einnig er rétt að nefna starfskenningar kennara, sem lítið virðist vera unnið með, og áherslur í kennaramenntun. Brýnt er að endurskoða hlutföllin í menntun framhaldsskólakennara, en aðaláherslan par hefur verið á fagmenntunina, án nægilegra tengsla við kennslu greinarinnar (OECD, 2012).

Auka parf fjölbreytni í símenntun kennara og færa hana meira inn í skólana og tengja hana betur próunarstarfi í skólanum, en símenntun framhaldsskólakennara hefur að mestu leyti falist í stuttum námskeiðum utan skólatíma. Gott dæmi um athyglisvert próunarstarf er tilraun sem Hjördís Dorgeirsdóttir lýsir í grein sinni frá 2018. Dar gerir hún grein fyrir árangri starfendarannsókna í einum framhaldsskóla sem lið í að endurskoða kennsluhætti.

Sjá mátti fjöldamörg dæmi um að kennarar sýndu nemendum kurteisi og elskulega framkomu og jafnvel samlíðan og sýnt var að margir peirra báru hag nemenda sinna fyrir brjósti, án pess pó að virðast reiðubúnir til að gefa peim hlutdeild í ákvörðunum um eigið nám. Бað voru of mörg dæmi um að ekki væri hlustað eftir röddum nemenda og peim væri ekki sýnd virðing, ábyrgð og traust samkvæmt skilgreiningum á nemendasjálfræði. Pau dæmi sem sáust um sjálfræði benda til pess að nemendur geti risið undir peirri ábyrgð sem felst í slíkum kennsluháttum. Mikilvægt er halda á lofti peim dæmum sem sýna að margir kennarar eru að stíga skref í pá átt og að slíkt er mögulegt innan pess ramma sem aðalnámskrá gefur.

Hinn skammi viðverutími í hverjum skóla takmarkar rannsóknina og pví liggja ekki fyrir fullnægjandi upplýsingar um pað að hve miklu eða litlu leyti er unnið í anda sjálfræðis og gilda pess. Ekki voru tök á að kanna hvort nemendur skildu markmið námsins eða hvort pau voru peim yfirleitt kunn. Markmiðin purfa að vera nemendum ljós og pað parf að leyfa peim að hafa áhrif á pau. Slík vinnubrögð eru hluti af pví að pjálfa nemendur til meira sjálfræðis. Við vitum heldur ekki að hve miklu leyti nemendur báru ábyrgð á námi sínu. Hin sterka skyndiprófahefð bendir reyndar ekki til pess að nemendum sé treyst og pví purfi petta stöðuga eftirlitskerfi (skyndiprófin). Рað bendir heldur ekki til pess að nemendur séu látnir meta skilvirkni eigin náms. Afar einstaklingsbundið er líka hversu vel slík námsmatsaðferð (próf) hentar hinum margbreytilega hópi sem stundar nám á framhaldsskólastigi.

Vettvangsathuganir sýndu ekki mörg dæmi um að nemendur væru hvattir til að ígrunda eða meta eigið nám, án pess pó að hægt sé að fullyrða að pað sé ekki gert. Í grein Valgerðar S. Bjarnadóttur (Í pessu sérriti) kemur fram að dagbókarskrif tíðkist eitthvað, en par hafa nemendur tækifæri til að ígrunda eigið nám. Fá dæmi sáust um skapandi verkefni par sem nemendur fengu að taka frumkvæði pótt einstaka kennari segðist aðspurður stundum vera með slík verkefni (sjá nánar um viðhorf kennara til skapandi verkefna grein Ástu Henriksen,Í pessu sérriti). Til að búa kennaranema undir að efla sjálfræði nemenda purfa peir að fá markvissa pjálfun í eigin námi; peir purfa að taka pátt í umræðum um námsmarkmið og inntak kennaranámsins og finna að rödd peirra skipti máli. Hvort og að hversu miklu leyti pað er gert í kennaranámi framhaldsskólakennara er ekki vitað. Til að mennta kennara til sjálfræðis parf að skipuleggja kennaranám pannig að peir kynnist nemendasjálfræði í raun í námi sínu og læri samfara pví aðferðir til að efla nemendasjálfræði og viti hvernig hægt er að skapa skilyrði sem styðja slíka breytingu á starfsháttum (Smith, 2003). 


\section{Lokaorð}

Lengi hefur verið ljóst að pað er flókið langtímaverkefni að próa kennsluhætti frá miðstýrðri kennslu yfir í kennsluhætti sem einkennast af hugmyndum um meiri nemendaábyrgð (Avalos, 2011; Fullan, 2007; Sarason, 1996) og engin ein leið er sú rétta til að bregðast við pví (Benson, 2013). Баð er hins vegar brýnt að huga að auknu sjálfræði í starfsháttum vegna hins fjölbreytta nemendahóps sem stundar nám í framhaldsskólum. Par gæu leiðir sem Stefanou og félagar (2004) benda á komið til greina, p.e. að leiða nemendur smám saman áfram í áttina til sjálfræðis.

Nærtækt er að álykta að meðal annars eigi ójafnvægi í grunnmenntun og veikburða símenntun framhaldskólakennara pátt í pví að efling lýðræðislegrar vitundar er ekki í forgangi og hefðbundnum miðstýrðum kennsluaðferðum er víða viðhaldið. Umgjörð til breytinga er fyrir hendi en telja má að pað sé einkum tvennt sem byrja purfi á að huga að hér á landi: Rannsaka hvort og pá hvernig og hvers vegna skólamenningin stendur í vegi fyrir róttækum breytingum og endurhugsa grunn- og símenntun framhaldsskólakennara. Drátt fyrir framsýna aðalnámskrá, par sem skólum er falið mikið vald og talsvert formlegt kennarasjálfræði, bendir pessi athugun ekki til að kennsluhættir sem efla sjálfræði hafi nád verulegri fótfestu.

\section{Aftanmálsgrein}

* Megingagnasöfnun í rannsókninni Starfshættir í framhaldsskólum fór fram á tímabilinu október 2013 til nóvember 2014 í níu framhaldsskólum, auk pess sem rannsóknartækin voru forprófuð í tíunda skólanum. Gögnin eru vettvangslýsingar á 130 kennslustundum, yfir 60 afrituð viðtöl við nemendur (hópviðtöl), kennara og stjórnendur, ljósmyndir úr kennslustofum, kennsluáætlanir og önnur skrifleg gögn. Fimmtán manna hópur fræðafólks við Menntavísindaog Félagsvísindasvið Háskóla Íslands tók pátt í gagnasöfnuninni. Rannsóknin naut styrkja úr Rannsóknarsjóði Háskóla Íslands á árunum 2013-2015 og frá Norræna öndvegissetrinu Justice Through Education in the Nordic Countries, styrktu af NordForsk, 2013-2018. Við pökkum sérstaklega framhaldsskólunum sem veittu aðgang að starfinu í rannsóknarskyni. 


\section{Exploring autonomy: Respect, responsibility, trust}

The importance of raising democratic awareness amongst young people has been at the centre of theoretical discussion throughout the 20th century. However, in order to raise this democratic awareness it is not sufficient to talk about democracy, it needs to be practised. The role of schools in this debate is, therefore, of the greatest importance. There are several options open to teachers and schools who want to develop democratic awareness amongst their learners. Introducing autonomy into the classroom is one approach towards this goal. Autonomy has been defined as the urge people have to be causal agents of their own life and actions; that is, autonomous learners need to be given more power and ownership over their own learning. Most definitions of learner autonomy have in common that learners set their own goals, take part in evaluating their own progress and by doing so take responsibility for their own learning. The values of respect and responsibility are interwoven with the concept of pedagogical autonomy and in the school context the value of trust also plays a vital role. In the autonomous classroom it is important to accept the learners' feelings toward their various assignments. Teachers need to reduce the pressure of testing, allowing students to take part in the evaluation process. Hence, for autonomy to succeed there has to be mutual trust between teachers and learners. Another criterion is that schools need to enjoy a certain freedom. The curriculum guide for upper secondary schools from 2011 gives schools quite a free rein to organise their own curriculum and considerable power and freedom is handed over to the schools; to both leaders and teachers. It can be argued that in many ways upper secondary schools have an unusually high degree of autonomy. In this paper the focus is on autonomy in the classroom. It is well documented that teacher autonomy is a prerequisite for learner autonomy and teacher autonomy necessitates teachers enjoying the competence, freedom and responsibility to choose their teaching practises and organise classroom work. The following research question was put forward: How is the concept of autonomy and its core values; respect, responsibility and trust reflected in teachers' practice and in the activities of teachers and students in the classroom? The study reported here is part of more extensive research aimed at obtaining a holistic view of the upper secondary school. The data on which this paper is based are 130 observations from classrooms, both academic and vocational classes, from nine schools, rural, as well as those in more densely populated areas. The basic data are researchers' interpretations of the observations where minute by minute descriptions are used to triangulate the data. After repeated readings of the data, five categories emerged, depending on how little or how much learner autonomy was observed. Those five categories were: teacher centred teaching, controlling by testing, effort and respect, toward autonomy, autonomy in praxis. Ten examples from all five categories are illustrated (verbatim) and discussed in relation to the core values underlying autonomy. The main findings indicate that teacher centred instruction remains the most conspicuous teaching approach and the student voice is absent most of the time. However, there were examples of various degrees of student autonomy and the observations suggest that many teachers are increasingly moving in that direction. When trying to speculate why teaching approaches are still so conservative and unvaried, several issues spring to mind which need to be investigated. One is the content and pedagogical approaches in initial teacher education and another relates to how in-service education (TPD) is organised. The scant research we have on teacher collaboration also indicates that collaboration needs closer scrutiny. In addition, the findings suggest that schools and teachers would benefit from more school based inservice education in schools and between schools.

Key words: National curriculum guide, teaching practices, student autonomy, teacher autonomy 


\section{Um höfundinn}

Hafdís Ingvarsdóttir (hei@hi.is) er professor emeritus. Hún lauk BA-prófi frá Háskóla Íslands og stundaði framhaldsnám við Kaupmannahafnarháskóla. Hún er með meistaragráðu í kennslufræði frá Háskólanum í Reading í Englandi með áherslu á tungumálanám og kennslu og doktorspróf í menntunarfræði frá sama skóla. Rannsóknir hennar hafa einkum beinst að framhaldsskólanum, starfskenningum kennara og starfproska peirra. Hún hefur einnig stundað rannsóknir á sviði tungumálanáms og -kennslu og hefur nýlokið langtímarannsókn á stöðu ensku á Íslandi.

\section{About the author}

Hafdís Ingvarsdóttir (hei@hi.is) is professor emeritus. She graduated with a BA degree from the University of Iceland followed by postgraduate studies at the University of Copenhagen. Hafdís holds a master's degree in Teaching and Instruction with emphasis on modern languages from the University of Reading, UK, and a $\mathrm{PhD}$ degree in Education from the same university. Her research mainly focuses on the upper-secondary school, teacher cognitions, teacher development, language teaching and learning. Her most recent publication is a longitudinal study on the status of English in Iceland.

\section{Heimildir}

Avalos, B. (2011). Teacher professional development in Teaching and Teacher Education over ten years. Teaching and Teacher Education, 27(1), 10-20.

Ásta Henriksen (2018). Sköpun skiptir sköpum:Viðhorf tungumálakennara til skapandi kennsluhátta. Netla - veftímarit um uppeldi og menntun. Sérrit 2018 - Framhaldsskólinn í brennidepli. Menntavísindasvið Háskóla Íslands. Sótt af http://netla.hi.is/serrit/2018/framhaldskolinn_brennidepli/08.pdf

Bernstein, B. (2000). Pedagogy, symbolic control, and identity: Theory, research, critique. Lanham: Rowman \& Littlefield.

Biesta, G. J.J. (2007). Education and the democratic person: Towards a political understanding of democratic education. Teachers College Record, 109(3), 740-769.

Black, A. E. og Deci, E. L. (2000). The effects of instructors' autonomy, support and students' autonomous motivation on learning organic chemistry: A self-determination theory perspective. Science Education, 84, 740-756.

Borg, S. og Alshumaimeri,Y. (2017). Language learner autonomy in a tertiary context:Teachers' beliefs and practices. Language Teaching Research 1-30, https://doi.org/10.1177/1362168817725759

Chamot, A. U. og Harris, V. (ritstjórar). (Í prentun). Learning strategy instruction in the language classroom: Issues and implementation. Bristol: Multilingual Matters.

Cohen,A. D. og Macaro, E. (2007). Language learner strategies:Thirty years of research and practice. Oxford: Oxford University Press.

Dam, L. (1995). Learner autonomy 3: From theory to practice. Dublin: Authentik.

Dewey, J. (1916/2007). Democracy and education. Teddington: The Echo Library (frumútgáfa 1916).

Fielding, M. (2004a). 'New wave' student voice and the renewal of civic society. London Review of Education, 2(3), 197-217. https://doi.org/10.1080/1474846042000302834

Fielding, M. (2004b). Transformative approaches to student voice: Theoretical underpinnings, recalcitrant realities. British Educational Research Journal, 30(2), 295-311.

Fullan, M. (2007). The new meaning of educational change (4. útgáfa). Oxford: Routledge.

Fullan, M. og Hargreaves, A. (2016). Bringing the profession back in: Call to action. Oxford, OH: Learning Forward.

Goddard, L. og Goddard, D. (2007). A theoretical and empirical investigation of teacher collaboration for school improvement and student achievement in public elementary schools. Teachers College Record, 109(4), 877-896.

Hafdís Ingvarsdóttir. (2006). ,... eins og pver geit i girðingu“.Viðhorf kennara til breytinga á kennsluháttum. Í Úlfar Haukssson (ritstjóri), Rannsóknir í félagsvísindum VIII (bls. 351-364). Reykjavík: Háskólaútgáfan. 
Hafdís Ingvarsdóttir. (2007). Námsaðferðir: Leiðir til árangursríkara tungumálanáms. Í Auður Hauksdóttir og Birna Arnbjörnsdóttir (ritstjórar), Mál málanna (bls. 295-310). Reykjavík: StofnunVigdísar Finnbogadóttur í erlendum tungumálum.

Hafdís Ingvarsdóttir. (2014). Reflection and work context in teacher learning: Two case studies from Iceland. Í C. Craig og L. Orlando (ritstjórar), International Teacher Education: Promising Pedagogies (Part A) (bls. 91-112). Bingley: Emerald Publishers.

Hattie, J.A. C. og Timperley, H. (2007). The power of feedback. Review of Educational Research, 77(1), 81-112.

Hjördís Porgeirsdóttir. (2018). The change room promotes teachers' agency to change their practice. Educational Action Research. doi:10.1080/09650792.2018.1436080

Ingibjörg Kaldalóns. (2017). Hvað hindrar kennara í að styðja sjálfræði nemenda í skólastarfi? Netla-Veftímarit um uppeldi og menntun. Sótt af http://netla.hi.is/serrit/2017/menntakvika_2017/004h

Jón Torfi Jónasson og Kristjana Stella Blöndal. (2002). Ungt fólk og framhaldsskólinn: Rannsókn á námsgengi og afstöðu ’75 árgangsins til náms. Reykjavík: Félagsvísindastofnun Háskóla Íslands.

Lalas, J. (2007). Teaching for social justice in multicultural urban schools: Conceptualization and classroom Implication. Education, 14(3), 17-21.

Leach, T. (2018). Democracy in the classroom. Power and Education, 10(2), 181-194.

Le Grange, L. og Reddy, C. (2000). Continuous assessment. An introduction and guidelines to implementation. Lansdowne, Suður-Afríka: Juta Legal and Academic Publishers.

Little, D. (1991). Learner autonomy: Definitions, issues and problems. Dublin: Authentik.

Little, D. (1995). Learning as dialogue:The dependence of learner autonomy on teacher autonomy. System, 23(2), 175-181.

Littlewood, W. (1999). Defining and developing autonomy in East Asian contexts. Applied Linguistics, 20(1), 71-94.

Lortie, D. (1975). Schoolteacher. Chicago: University of Illinois Press.

Mennta- og menningarmálaráđuneytið. (2011). Aðalnámskrá framhaldsskóla. Reykjavík:

Miles, M. B. og Huberman,A. M. (1994). Qualitative data analysis: An expanded sourcebook (2. útgáfa).Thousand Oaks, CA: Sage.

Mitra, D. L. (2004). The significance of students: Can increasing "student voice" in schools lead to gains in youth development? Teachers College Record, 106(4), 651-688.

Niemiec, C. P. og Ryan, R. M. (2009). Autonomy, competence, and relatedness in the classroom. Applying self-determination theory to educational practice. Theory and Research in Education, 7(2), 133-144.

OECD [Organization for Economic Co-operation and Development]. (2012). Towards a strategy to prevent dropout in Iceland: Result of the OECD-Iceland workshop on preventing dropout in upper secondary schools in Iceland. Sótt af https://www.oecd.org/iceland/49451462.pdf

Oser, F. K., Dick, A. og Patry, J. (ritstjórar). (1992). Effective and responsible teaching. San Francisco: Jossey-Bass.

Parker, G. (2015). Teachers' autonomy. Research in Education, 93 (1), 19-33. doi:10.7227/RIE.0008

Patton, M. Q. (1994). Qualitative research E evaluation methods. Integrating theory and practice. Thousand Oaks, CA: Sage.

Pearson, L. C. og Moomaw, W. (2005). The relationship between teacher autonomy and stress, work satisfaction, empowerment, and professionalism. Educational Research Quarterly, 29(1), 37-53.

Pelletier, L. G. og Sharp, E. C. (2009). Administrative pressures and teachers' interpersonal behaviour in the classroom. Theory and Research in Education, 7(2), 174-183. doi:10.1177/1477878509104322

Reeve, J. (2009). Why teachers adopt a controlling motivating style toward students and how they can become more autonomy supportive. Educational Psychologist, 44(3), 159-175.

Ryan, R. M. og Deci, E. (2000). Self-determination theory and the facilitation of intrinsic motivation, social development, and well-being. American Psychologist, 55(1), 68-78.

Sarason, S. B. (1996). Revisiting "The culture of the school and the problem of change" (2. útgáfa). New York: Teachers College Press. 
Sigrún Aðalbjarnardóttir. (2007). Virðing og umhyggja-Ákall 21. aldar. Reykjavík: Heimskringla, Háskólaforlag Máls og menningar.

Sigrún Aðalbjarnardóttir. (2015). Ákall og áskoranir:Vegsemd og virðing í skólastarfi. Netla - Veftímarit um uppeldi og menntun. Sótt af http://netla.hi.is/greinar/2015/alm/005.pdf

Skott,J. (2014).The promises, problems and prospects of research on teachers' beliefs. Í H. Fives og M. G. Gill (ritstjórar), International handbook of research on teachers' beliefs (bls. 13-30). London: Routledge.

Smith, R. C. (2003). Teacher education for teacher-learner autonomy. [Málstofa fyrir kennara sem mennta tungumálakennara. Greinasafn frá IALS-málstofu í Edinborg].

Stefanou, C. R., Perencevich, K. C., DiCintio, M. og Turner, J. C. (2004). Supporting autonomy in the classroom: Ways teachers encourage student decision making and ownership. Educational Psychologist, 39(2), 97-110.

Steinunn Gestsdóttir. (2012). Sjálfstjórnun barna og ungmenna: Staða pekkingar og pýðing fyrir skólastarf. Uppeldi og menntun, 21(2), 19-41.

Valgerður S. Bjarnadóttir (2018). Building bridges and constructing walls: Subject hierarchies as reflected in teachers' perspectives towards student influence. Netla - veftímarit um uppeldi og menntun. Sérrit $2018-$ Framhaldsskólinn í brennidepli. Menntavísindasvið Háskóla Íslands. Sótt af http://netla.hi.is/serrit/2018/ framhaldskolinn_brennidepli/04.pdf

Warren Little,J. (1990). The persistence of privacy:Autonomy and initiative in teachers' professional relations. Teachers College Record, 91(4), 459-453.

Wideen, M. (1994). The struggle for change: A case study of one school. London: Falmer.

Hafdís Ingvarsdóttir. (2018).

Kennsluhættir speglaðir í ljósi sjálfræðis: Virðing, ábyrgð og traust.

Netla - veftímarit um uppeldi og menntun. Sérrit 2018 - Framhaldsskólinn í brennidepli.

Menntavísindasvið Háskóla Íslands.

Sótt af http://netla.hi.is/serrit/2018/framhaldskolinn_brennidepli/03.pdf

DOI: https://doi.org/10.24270/serritnetla.2019.3 